\title{
Analisis Persebaran Medan Listrik Pada Lightning Arrester 20 kV Menggunakan Finite Element Method
}

\author{
A A Gd Dharma Putera, I Made Yulistya Negara, dan Daniar Fahmi \\ Jurusan Teknik Elektro, Fakultas Teknologi Industri, Institut Teknologi Sepuluh Nopember (ITS) \\ J1. Arief Rahman Hakim, Surabaya 60111 \\ E-mail: Agunggede.dharmaputera@gmail.com, yulistya@ee.its.ac.id, daniarfahmi@ee.its.ac.id
}

\begin{abstract}
Abstrak-Lightning Arrester adalah perangkat semikonduktor yang digunakan dalam sistem tenaga listrik untuk melindungi peralatan terhadap petir dan switching tegangan lebih. Alat pelindung terhadap gangguan petir ini berfungsi melindungi peralatan sistem tenaga listrik dengan membatasi tegangan lebih yang datang dan mengalirkannya ke tanah. Arrester tidak akan bekerja pada keadaan normal melainkan akan bekerja pada saat adanya tegangan impuls yang datang pada arrester. Dalam penggunaanya arrester ini akan menimbulkan medan pada permukaan arrester. Pada tugas akhir ini dilakukan pemodelan untuk menganalisa persebaran medan listrik pada arrester tersebut. Analisa pemodelan medan listrik membantu dalam mengetahui pengaruh dari itensitas medan maksimum dalam arrester baik dalam kondisi normal maupun transien. Metode yang digunakan adalah simulasi yang berbasis pada FEM (finite element method). Serta membandingkan kondisi medan listrik pada permukaan arrester dalam keadaan normal, terkontaminasi air garam, saat terdapat rongga udara dan terkontaminasi debu. Akan diketahui hasil dari simulasi nilai medan listrik saat diberikan tegangan nominal sangat tinggi dibandingkan dengan saat diberikan arus impuls yang nilai medannya sangat kecil.
\end{abstract}

Kata Kunci : Lightning Arrester, Impuls, Kontaminan Air Garam Debu dan Rongga Udara, Finite Element Method

\section{PENDAHULUAN}

$\mathrm{L}$ ightning arrester merupakan perangkat semikonduktor yang digunakan dalam sistem tenaga listrik untuk melindungi terhadap petir dan switching tegangan lebih. Tegangan lebih adalah faktor pembatas untuk merancang sistem tegangan tinggi [1]. Alat pelindung terhadap sambaran petir ini berfungsi melindungi peralatan system tenaga listrik dengan cara membatasi tegangan petir yang datang dan mengalirkannya ke tanah [2]. Arrester dipasang antara fase dan bumi dan bertindak sebagai jalan simpangan untuk tegangan yang impuls, arrester dirancang menjadi isolator untuk tegangan operasi nominal menyalurkan arus paling sedikit dalam milliamperes dan mampu menjadi konduktor yang bagus [3].

Medan listrik di sekitar arrester dipengaruhi oleh geometri arrester dan karakteristik listrik bahan yang berpartisipasi. Pemodelan medan listrik membantu dan mempertimbangkan faktor-faktor penting yang mempengaruhi intensitas medan maksimum dalam arester, terutama selama kondisi transien dan fenomena yang dapat menyebabkan kerusakan pada arrester [3]. Distribusi tegangan tergantung pada geometri sebagai serta sifat listrik dari bahan perakitan arrester [4].

Pada studi kali ini simulasi berbasis FEM (Finite Element Method) digunakan untuk menganalisa distribusi medan listrik pada lightning arrester serta membandingkan kondisi medan listrik pada permukaan lightning arrester normal dengan keadaan yang terkontaminasi air garam. Dan membandingkan medan listrik pada permukaan lightning arrester dalam keadaan rusak dengan kondisi normal atau baik.

\section{PENGERTIAN LIGHTNING ARRESTER DAN JENIS KONTAMINAN}

\section{A. Lightning Arrester}

Lightning arrester atau arrester merupakan alat pelindung terhadap tegangan lebih. Arrester sendiri dipasang pada atau dekat peralatan yang dihubungkan dari fasa konduktor ke tanah. Alat ini akan bekerja pada tegangan tertentu di atas dari tegangan operasi yang berfungsi untuk membuang muatan listrik dari surja petir dan berhenti beroperasi pada tegangan tertentu di atas tegangan operasi agar tidak terjadi arus pada tegangan operasi. Lightning arreter dipasang paralel dengan peralatan yang dilindungi. Lokasinya diatur sehingga tegangan lebih impuls melalui alat pelindung terlebih dulu sebelum melewati alat yang dilindungi. Pada keadaan tegangan normal, arrester berperan sebagai isolasi atau idealnya tidak mengalirkan arus dari jaringan ke tanah.

\section{B. Pembentukan Sudut Kontak Air Pada Permukaan Arrester}

Sudut kontak merupakan sudut yang terbentuk antara dua batas permukaan yaitu air dengan permukaan arrester. Sifat hydrophobic pada suatu permukaan arrester mempengaruhi besar sudut kontak air yang menempel di permukaan arrester.

Besar sudut kontak air pada suatu permukaan dapat dibagi menjadi tiga macam, yaitu :

1. Basah keseluruhan

Sudut kotak yang terbentuk antara butir air dengan permukaan arrester kurang dari 90 derajat.

2. Basah sebagian

Sudut kotak yang terbentuk antara butir air dengan permukaan arrester pada sekitar 90 derajat.

3. Hampir tidak basah

Sudut kotak yang terbentuk antara butir air dengan permukaan arrester pada lebih dari 90 derajat. 


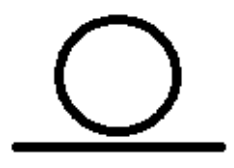

$>90^{\circ}$

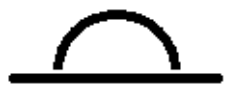

$90^{\circ}$

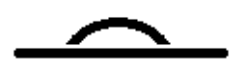

$<90^{\circ}$
Gambar 1. Pembentukan sudut kontak permukaan arrester

\section{Rongga Udara (void) Pada Permukaan Arrester}

Rongga udara atau void pada permukaan arrester dapat menyebabkan kerja dari arrester tidak maksimal. Beberapa hal yang menyebabkan adanya rongga udara pada suatu arrester antara lain adalah kesalahan pada saat pembuatan. Rongga udara ini dapat mengurangi kemampuan dielektrik dan kemampuan hydrofobik suatu arrester. Rongga kecil pada arrester lama-kelamaan akan menyebabkan kerusakan mekanik pada arrester. Rongga udara ini juga mampu mempengaruhi nilai medan listrik pada arrester.

\section{Kontaminan Debu Pada Permukaan Arrester}

Kontaminan debu pada permukaan arrester menyebabkan kinerja arrester tidak maksimal. Arrester diletakkan di ruang terbuka dan terdekat dengan alat yang dilindunginya, hal tersebut menyebabkan menempelnya debu pada permukaan arrester. Kontaminan debu dapat mengurangi kemampuan dielektrik arrester.

\section{METODE DAN SIMULASI LIGHTNING ARRESTER}

\section{A. Metode Element Hingga (FEM)}

Metode elemen hingga merupakan salah satu metode numerik yang sering digunakan untuk menyelesaikan permasalahan struktur termal dan elektromagnetik. Dalam proses diskretisasi, untuk memodelkan bentuk satu, dua atau tiga dimensi suatu benda atau daerah yang dianalisis dibagi kedalam bentuk mesh (kumpulan elemen) yang saling terhubung. Tipe masalah yang dapat diselesaikan dengan metode elemen hingga terbagi menjadi dua kelompok, yaitu kelompok analisis struktur dan kelompok analisis nonstruktur. Dalam studi kali ini analisis yang digunakan adalah analisis non-struktur yaitu analisis yang digunakan untuk menganalisi kejadian transfer panas, aliran fluida, distribusi dari potensial medan magnet dan medan listrik.

\section{B. Perhitungan Medan Listrik dan Energi pada Medan Listrik [5]}

Medan listrik adalah efek yang ditimbulkan oleh keberadaan muatan listrik seperti elektron, proton dan ion yang berada pada ruangan di sekitar daerah yang terukur. Medan listrik dan gaya Coulomb memiliki fungsi dan persoalan yang saling berhubungan. Rumus matematika untuk medan listrik merupakan penurunan dari hukum Coulomb.

$$
E=\frac{q}{4 \pi \varepsilon_{0} R^{2}} a_{1 t}
$$

Apabila diketahui milai potensial listrik (V), maka medan listrik juga dapat dihitung melalui gradiennya :

$$
\nabla V=\frac{\partial V}{\partial x} a_{x}+\frac{\partial V}{\partial y} a_{y}+\frac{\partial V}{\partial z} a_{z}
$$

Sehingga didapatkan nilai E :

$$
E=-\nabla V
$$

Pada medan listrik tentu memiliki muatan energi $\left(\mathrm{W}_{\mathrm{E}}\right)$ yang tersimpan di dalamnnya, energi tersebut dapat dihitung menggunakan rumus :

$$
W_{E}=\frac{1}{2} \int_{V o l} \rho_{v} V d v
$$

Total energi $\left(\mathrm{W}_{\mathrm{E}}\right)$ yang tersimpan pada medan listrik dalam suatu volume, adalah :

$$
W_{E}=\frac{1}{2} \int_{V} \varepsilon(\nabla V)^{2} d v
$$

\section{Perhitungan Medan dengan Metode Elemen Hingga}

Nilai potensial listrik (V) memiliki hubungan dengan kerapatan flux listrik (D). Untuk mengetahui hubungan potensial listrik dengan flux listrik, dapat digunakan persamaan Maxwell. Dari persamaan Maxwell tersebut dapat diketahui hubungan potensial listrik dengan kerapatan flux.

$$
\nabla . D=\rho_{v}
$$

Hubungan flux listrik (D) dan medan listrik (E),

$$
D=\varepsilon_{0} \varepsilon_{r} E
$$

dimana,

$$
\varepsilon_{0} \varepsilon_{r}=\varepsilon
$$

Bila polarisasi dianggap nol, diperoleh persamaan,

$$
\nabla . \nabla V=-\frac{\rho_{v}}{\varepsilon}
$$

Keterangan :

$\mathrm{E}=$ Intensitas Medan Listrik $(\mathrm{V} / \mathrm{m})$

$\mathrm{V}=$ Potensial Listrik $(\mathrm{V})$

$\mathrm{D}=$ Kerapatan Fluks Listrik $\left(\mathrm{C} / \mathrm{m}^{2}\right)$

Persamaan 6 diatas merupakan persamaan poisson. Pada persamaan poisson tersebut memiliki nilai gradien potensial yang dapat diuraikan menjadi persamaan sebagai berikut :

$$
\nabla^{2} V=\frac{\partial^{2} V}{\partial x^{2}} a_{x}+\frac{\partial^{2} V}{\partial y^{2}} a_{y}+\frac{\partial^{2} V}{\partial z^{2}} a_{z}=-\frac{\rho_{v}}{\varepsilon}
$$

Persamaan laplace 10 bila dirumuskan dalam koordinat kartesius diumpakan nilai 0 , dapat menjadi bentuk persamaan :

$$
\nabla^{2} V=\frac{\partial^{2} V}{\partial x^{2}} a_{x}+\frac{\partial^{2} V}{\partial y^{2}} a_{y}+\frac{\partial^{2} V}{\partial z^{2}} a_{z}=0
$$

Dimana nilai $\rho_{v}=0$

\section{Perhitungan Medan pada Elemen Segitiga}

Dalam menyelesaikan perhitungan distribusi medan listrik pada arrester dengan menggunakan metode elemen hingga, arrester dibagi kedalam bentuk elemen segitiga. Bila kita dapat menentukan atau mengetahui nilai potensial (V) pada tiap elemen segitiga dan menghitung nilai medan listriknya pada setiap elemen segitiga maka akan diketahui nilai distribusi medan listrik pada arrester. Nilai potensial listrik terletak pada titik yang terdapat pada tiap sudut segitiga. Setiap nilai 
potensial listrik yang terdapat pada setiap elemen segitiga dihubungkan antara satu dengan yang lain.

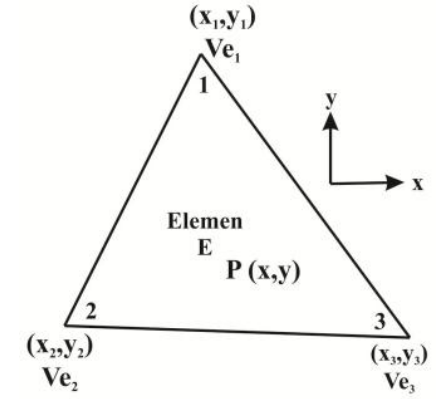

Gambar 2. Element segitiga pada suatu domain

Persamaan mencari energi pada medan elektrostatik untuk tiap elemen dapat didapatkan dari fungsi berikut:

$$
W_{E}=\frac{1}{2} \varepsilon_{0} \varepsilon_{r} V^{T} S V
$$

Setelah arrester dideskretisasi menjadi bentuk elemen segitiga dan memiliki nilai potensial pada setiap elemen segitiganya, maka dapat dilakukan perhitungan potensial listrik pada seluruh bagian arrester dengan menyatukan tiaptiap elemen segititga kecil menjadi satu bentuk arrester yang utuh.

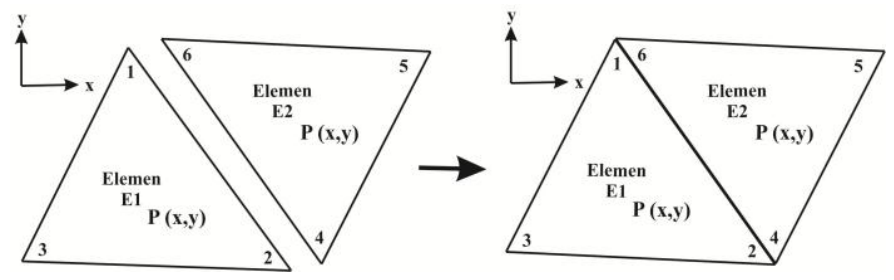

Gambar 3. Penggabungan dua element segitiga

Dari penggabungan beberapa elemen segitiga tersebut didapatkan nilai energinya :

$$
W=\frac{1}{2} \varepsilon_{0} \varepsilon_{r} V_{\text {con }}^{T} S V_{\text {con }}
$$

Dengan,

$$
S=C^{T} S_{d i s} C
$$

Persamaan (14) dapat dijabarkan menjadi suatu matrik koefisien yang terhubung antar satu segitiga dengan yang lainnya. Matriks koefisiensi dari pengabungan dua element segitiga seperti pada gambar 3 adalah :

$$
S=\left[\begin{array}{llllcc}
S_{11}^{(1)}+ & S_{66}^{(2)} & S_{12}^{(1)}+ & S_{64}^{(2)} & S_{13}^{(1)} & S_{65}^{(2)} \\
S_{21}^{(1)}+ & S_{46}^{(2)} & S_{22}^{(1)}+ & S_{44}^{(2)} & S_{23}^{(1)} & S_{45}^{(2)} \\
S_{31}^{(1)} & & S_{32}^{(1)} & & S_{33}^{(1)} & 0 \\
S_{56}^{(1)} & & S_{54}^{(1)} & & 0 & S_{55}^{(2)}
\end{array}\right]
$$

\section{E. Pemodelan Metal Oxide Lightning Arrester}

Arrester yang dimodelkan sesuai dengan standar ANSI/IEEE C62.11-2005 adalah metal oxide lightning arrester dengan bahan zinc oxide ( $\mathrm{ZnO})$ dan tanpa gap atau gapless.

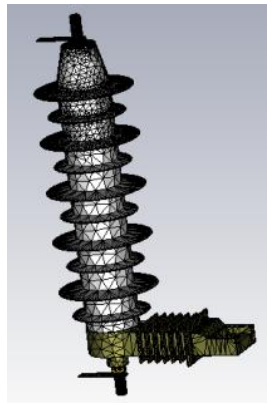

Gambar 4. Pemodelan elemen segitiga pada metal oxide lightning arrester

\section{F. Simulasi Pengaruh Kontaminan Air pada Metal Oxide Lightning Arrester}

Untuk melihat dampak dari pembentukan sudut kontak terhadap medan listrik pada permukaan arrester, akan dilakukan simulasi pada sirip pertama arrester dengan menggunakan air garam sebagai kontaminannya.

Ada tiga kondisi yang digunakan pada simulasi kali ini, yaitu :

1. Kondisi butir air 1

Pada kondisi ini, butiran air memiliki sudut kontak $>90^{\circ}$

2. Kondisi butir air 2

Pada kondisi ini, butiran air memiliki suduk kontak $90^{\circ}$

3. Kondisi butir air 3

Pada kondisi ini, butiran air memiiki sudut kontak $<90^{\circ}$

Pembentukan sudut kontak air garam pada permukaan sirip pertama arrester berpengaruh terhadap nilai medan listrik. Hal tersebut dipengaruhi oleh 2 hal, yaitu :

1. Sudut kontak pembentukan butir air garam

2. Nilai epsilon antara air garam, udara dan bahan arrester

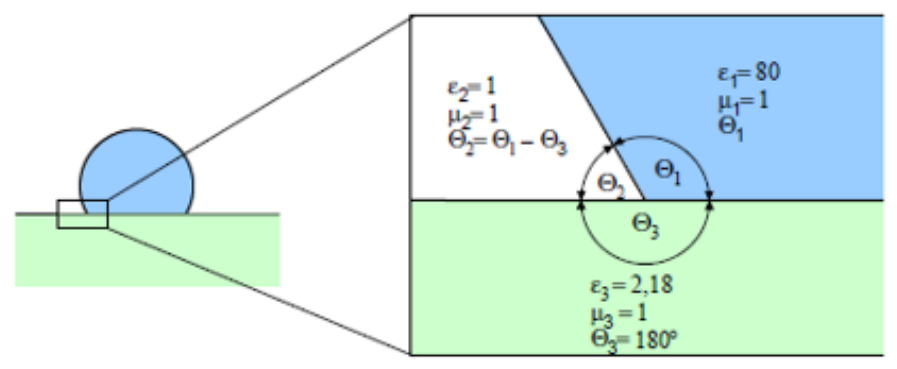

Gambar 5. Pengaruh sudut kontak dan nilai epsilon

Dimana epsilon ( $\varepsilon$ ) adalah permivitas dari bahan dan $\theta$ merupakan sudut yang terbentuk dari persinggungan ketiga dielektrik antara butir air garam, udara dan bahan permukaan arrester yang terkena butir air.

Dalam hal ini, nilai medan listrik pada permukaan arrester dapat diketahui melalui persamaan berikut :

$$
E_{\rho}=\sum_{n=0}^{\infty} \mathrm{a}_{n} \rho^{t+n-1}
$$

Dan

$$
E_{\varphi}=\sum_{n=0}^{\infty} \mathrm{b}_{n} \varphi^{t+n-1}
$$

Nilai $E_{\rho}$ dan $E_{\varphi}$ tergantung dari jarak $\rho$ dan $\varphi$, posisi dari persinggungan ketiga titik dielektrik, singularitas eksponen $t$ dan faktor $a_{n}$ dan $b_{n}$. 


\section{G. Simulasi Pengaruh Rongga Udara pada Permukaan Arrester}

Salah satu faktor yang dapat mempengaruhi kemampuan dielektrik arrester untuk menahan medan listrik adalah kondisi permukaan arrester tersebut. Besar kecilnya rongga udara atau void pada permukaan arrester, maka akan berpengaruh juga pada nilai medan listrik yang mengenai arrester tersebut dan nilai medan listriknya akan berubah. Sehingga dapat di analisis pengaruh rongga udara terhadap medan listrik pada sirip pertama arrester.

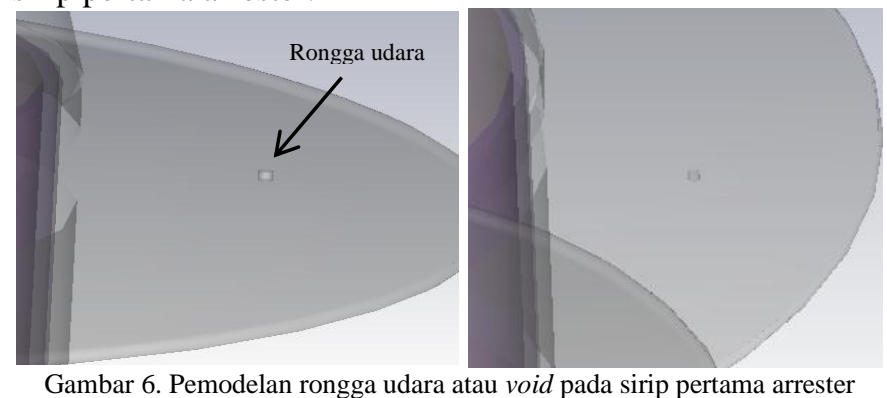

\section{H. Simulasi Pengaruh Kontaminan Debu pada Permukaa} Arrester

Kondisi dengan kontaminan yang terdapat pada permukaan arrester ini tentunya akan mempengaruhi kondisi dielektrik arrester untuk menahan medan listrik. Tebal dan tipisnya debu yang menempel pada permukaan arrester akan mempengaruhi nilai medan listrik yang mengenai arrester dan nilai medan listrik tersebut akan berubah. . Sehingga dapat di analisis pengaruh kontaminan debu terhadap kondisi medan listrik pada sirip pertama arrester.

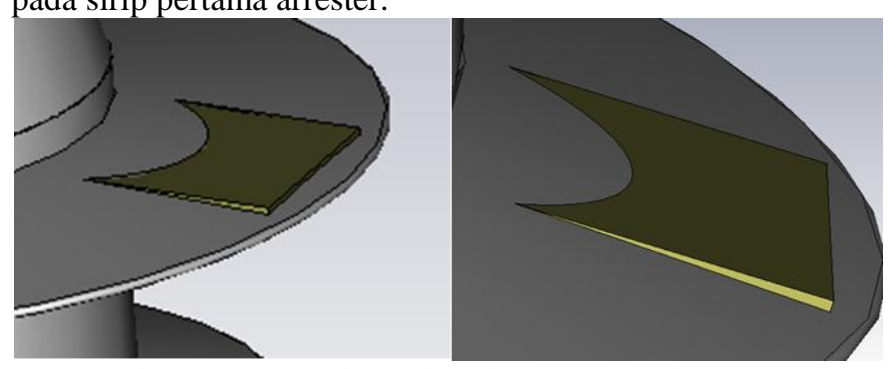

Gambar 7. Pemodelan kontaminan debu pada permukaan arrester

\section{HASIL SIMULASI DAN ANALISA DATA}

\section{A. Tegangan Kerja Arrester}

Tegangan normal yang digunakan pada arrester ini sesuai dengan tegangan nominal arrester, yaitu $20 \mathrm{kV}$. Pada simulasi kali ini, digunakan arus impuls dengan nilai yang cukup besar yaitu $20 \mathrm{kA}$ agar arrester bekerja sebagai penghantar.

\section{B. Perbandingan Kurva Medan Listrik pada Badan Arrester Pada Saat terkena Tegangan Nominal dan Arus Impuls}

Dari gambar 8 menunjukkan perbandingan nilai medan listrik pada badan arrester saat terkena tegangan nominal dan arus impuls. Pada nilai medan listrik saat terkena tegangan nominal pengisian awalnya sebesar $1,35 \times 10^{2} \mathrm{kV} / \mathrm{m}$ dan mengalami penurunan secara berkala sampai di titik terbawahnya sebesar $0,39 \times 10^{2} \mathrm{kV} / \mathrm{m}$. Sedangkan pada saat arrester terkena arus impuls pengisian awal nilai medan listrik teratas adalah sebesar $0,97 \mathrm{kV} / \mathrm{m}$ dan mengalami penurunan secara berkala hingga mencapai titik terbawahnya sebesar 0,16 $\mathrm{kV} / \mathrm{m}$. Secara bentuk kurva dapat dilihat nilai medan listrik sangat jauh berbeda, itu dikarenakan saat terkena arus impuls tegangannya sangat kecil atau hampir mendekati nol bila dibandingkan dengan tegangan nominal yang diberikan. Namun bentuk kuva memiliki bentuk yang hampir sama, dimana terjadi peningkatan nilai medan listrik pada bagian yang terdapat sirip arrester.

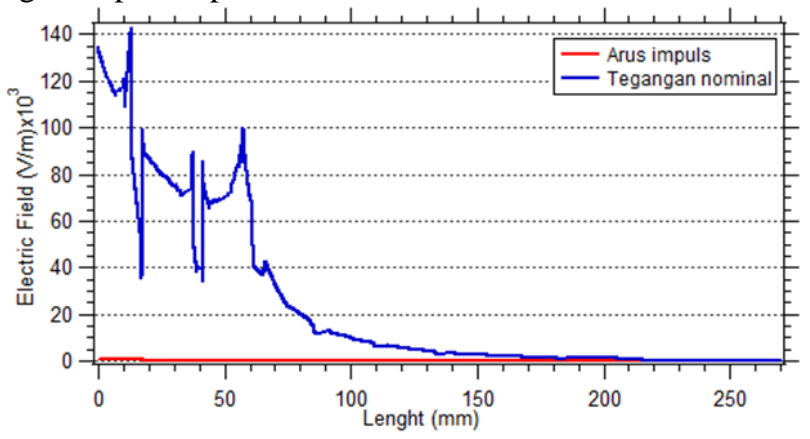

Gambar 8. Kurva perbandingan nilai medan listrik saat terkena tegangan nominal dan arus impuls

\section{Perbandingan Kurva Medan Listrik Antar Sirip Arrester} Pada Saat Diberikan Tegangan Nominal dan Arus Impuls

Dari gambar 9 menunjukkan perbandingan nilai medan listrik antar sirip arrester saat diberikan tegangan nominal dan arus impuls. Pada nilai medan listrik saat terkena tegangan nominal pengisian awalnya sebesar $1,41 \times 10^{2} \mathrm{kV} / \mathrm{m}$ dan mengalami penurunan secara berkala sampai di titik terbawahnya sebesar $0,2 \times 10^{2} \mathrm{kV} / \mathrm{m}$. Sedangkan pada saat terkena arus impuls pengisian awal nilai medannya sebesar $0,93 \mathrm{kV} / \mathrm{m}$ dan mengalami penurunan secara sigifikan hingga mencapai titik terbawahnya sebesar $0,11 \mathrm{kV} / \mathrm{m}$. Secara bentuk kurva dapat dilihat nilai medan listrik jauh berbeda, itu dikarenakan pada saat terkena arus impuls tegangannya sangat kecil atau hampir mendekati nol bila dibandingkan dengan tegangan nominal yang diberikan.

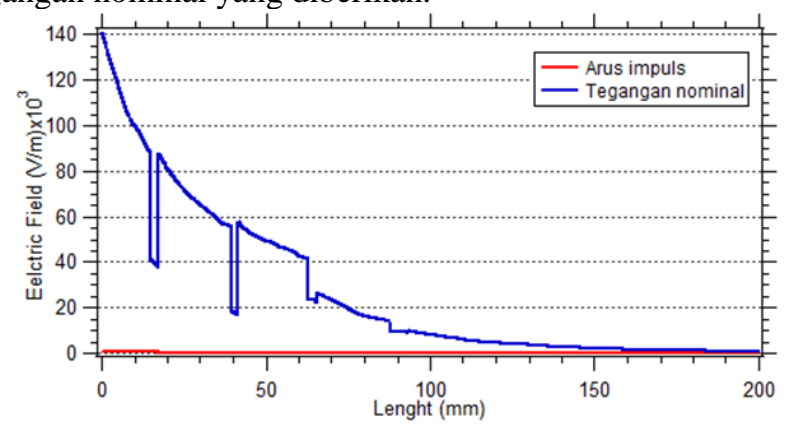

Gambar 9. Kurva perbandingan nilai medan listrik antar sirip pada arrester saat terkena tegangan nominal dan arus impuls

\section{Pengaruh Kontaminan Air Garam Terhadap Medan Listrik pada Sirip Pertama Arrester}

\section{Pengaruh Kontaminan Air Garam I, II dan III Terhadap}

Medan Listrik pada Sirip Pertama Arrester

Berikut merupakan pengaruh kontaminan air garam dapat dilihat pada penarikan garis biru merupakan bagian yang diukur nilai medan listriknya. Dapat dilihat dari hasil ketiga kurva pembentukan sudut kontak air garam mempengaruhi nilai medan listrik pada permukaan sirip pertama arrester. Nilai medan listrik akan naik di setiap titik persudutan butiran 
air garam. Hal ini disebabkan oleh sudut kontak yang dibentuk oleh air garam dan membuat medan terkumpul pada titik persudutannya. Nilai medan listrik saat terkontaminan air garam berubah-ubah dikarenakan di setiap sisi persudutannya merupakan titik persinggungan dielektrik antara zat cair, zat gas dan zat padat, sehingga pada titik tersebut nilai medan menjadi sangat besar.
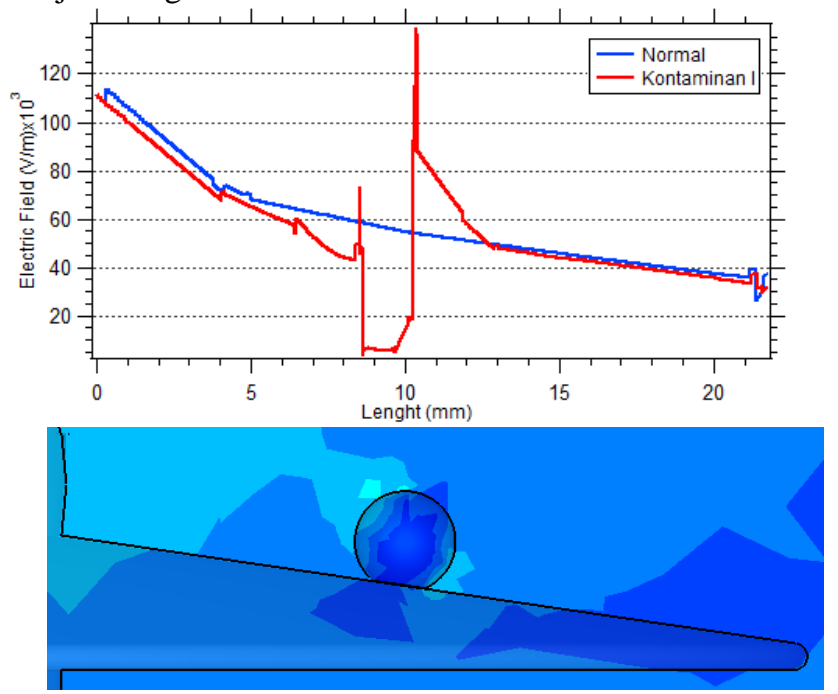

Gambar 10. Kurva nilai medan listrik pada sirip pertama arrester dengan
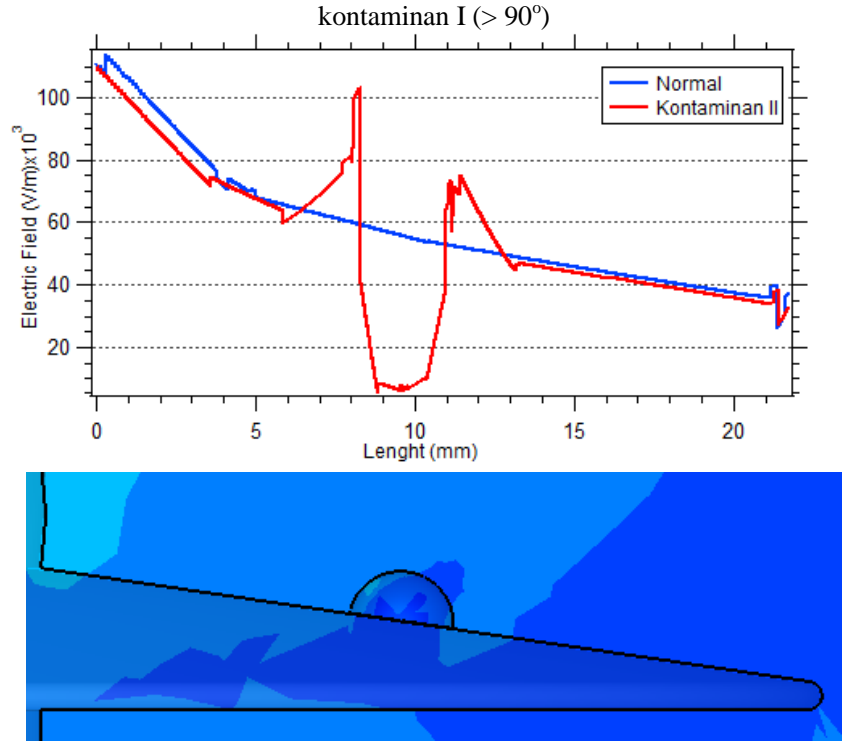

Gambar 11. Kurva nilai medan listrik pada sirip pertama arrester dengan kontaminan II $\left(90^{\circ}\right)$

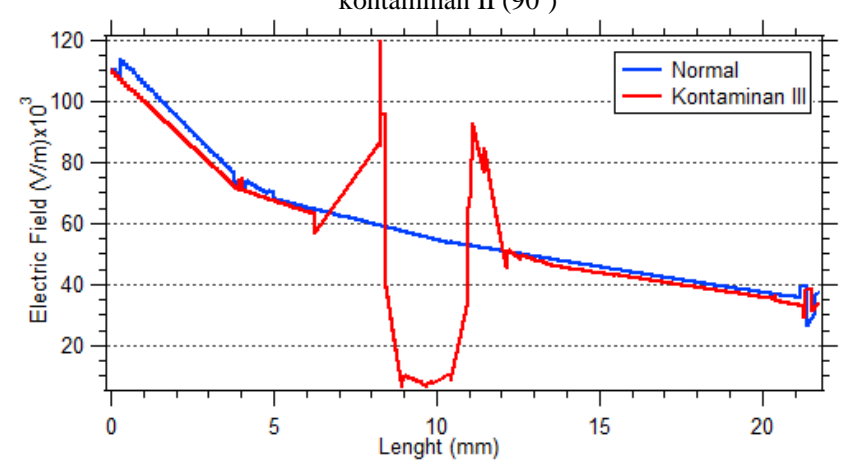

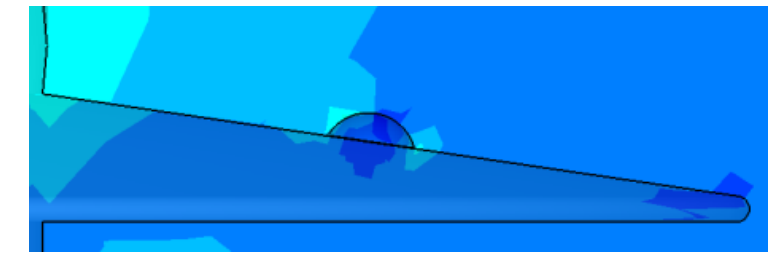

Gambar 12. Kurva nilai medan listrik pada sirip pertama arrester dengan kontaminan III $\left(<90^{\circ}\right)$

2. Perbandingan Pengaruh Kontaminan Air Garam I, II dan III Terhadap Medan Listrik pada Sirip Pertama Arrester Saat Diberikan Tegangan Nominal dan Arus Impuls

Secara bentuk kurva dapat dilihat nilai medan listrik jauh berbeda, itu dikarenakan pada saat terkena arus impuls tegangannya sangat kecil atau hampir mendekati nol bila dibandingkan dengan tegangan nominal yang diberikan. Kedua kurva ini memiliki bentuk yang sangat jauh berbeda tetapi memiliki kesamaan nilai medan listrik akan naik di setiap titik persudutan butiran air garam. Hal ini disebabkan oleh sudut kontak yang dibentuk oleh air garam dan membuat medan terkumpul pada titik persudutannya.. Pada saat mengenai butiran air garam terjadi perubahan nilai medan yang cukup signifikan.

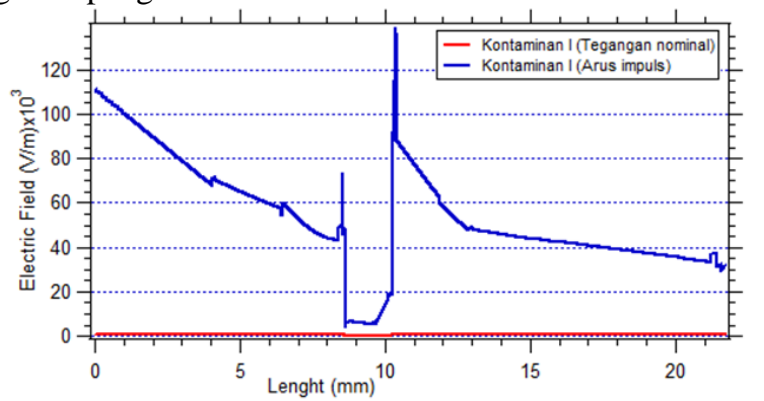

Gambar 13. Kurva perbandingan nilai medan listrik pada sirip pertama arrester saat diberikan tegangan nominal dan arus impuls dengan kontaminan I $\left(>90^{\circ}\right)$

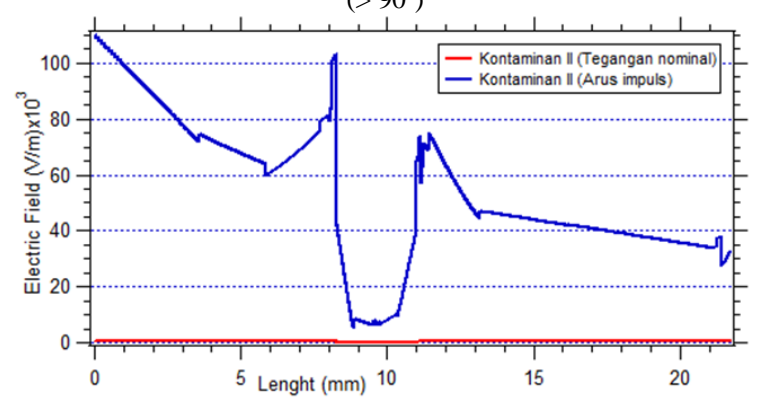

Gambar 14. Kurva perbandingan nilai medan listrik pada sirip pertama arrester saat diberikan tegangan nominal dan arus impuls dengan kontaminan II $\left(90^{\circ}\right)$

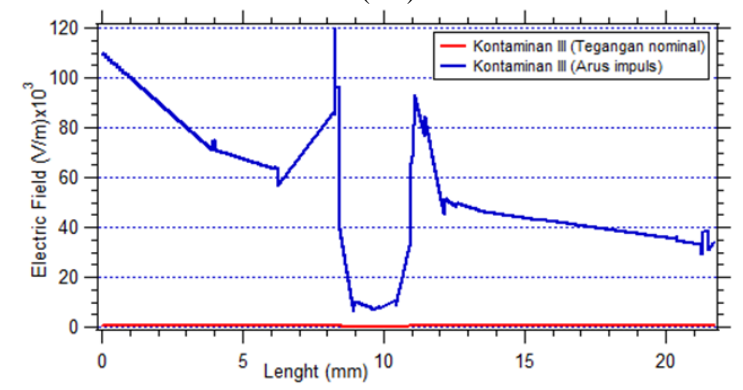

Gambar 15. Kurva perbandingan nilai medan listrik pada sirip pertama arrester saat diberikan tegangan nominal dan arus impuls dengan kontaminan III $\left(<90^{\circ}\right)$ 


\section{E. Perbandingan Nilai Medan Listrik Pada Sirip Pertama Arrester saat Kondisi Normal dan Adanya Rongga Udara}

Pada gambar 16 menunjukkan perbandingan nilai medan listrik pada sirip pertama arrester saat kondisi normal dan adanya rongga udara (void). Dapat dilihat pengisian awal nilai medan listrik pada saat keadaan normal adalah sebesar $1,14 \times$ $102 \mathrm{kV} / \mathrm{m}$ dan nilai medan pada saat adanya void pada sirip pertama arrester sebesar $1,15 \times 102 \mathrm{kV} / \mathrm{m}$. Adanya void pada sirip pertama arrester mempengaruhi kemampuan dielektrik sirip pertama arrester pada bagian pembungkus polimer.

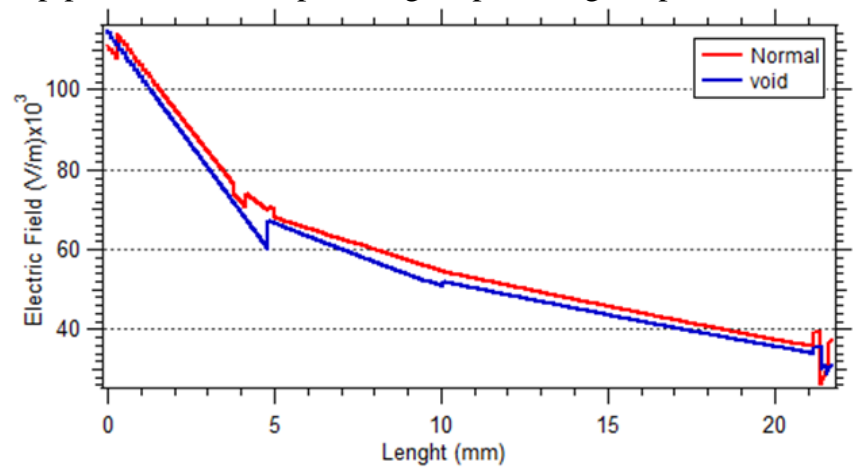

Gambar 16. Kurva perbandingan nilai medan listrik saat kondisi normal dan saat adanya rongga udara (void)

F. Perbandingan Nilai Medan Listrik Pada Sirip Pertama Arrester saat Kondisi Normal dan Adanya Kontaminan Debu

Pada gambar 17 menunjukkan perbandingan nilai medan listrik pada sirip pertama arrester saat kondisi normal dan terdapat kontaminan debu. Dapat dilihat pengisian awal nilai medan listrik pada saat keadaan normal adalah sebesar $1,14 \times$ $10^{2} \mathrm{kV} / \mathrm{m}$ dan nilai medan pada saat adanya kontaminan debu pada sirip pertama arrester sebesar $1,14 \times 10^{2} \mathrm{kV} / \mathrm{m}$. Kontaminan debu mempengaruhi sifat dielektrik arrester terutama pada bagian sirip pertama yang terdapat debu. Nilai medan listrik menurun pada saat mulai terkena daerah kontaminan yang tipis dan semakin menurun seiring dengan semakin tebal penumpukan kontaminan debu. Nilai medan listrik pada saat mulai terkena kontaminan dan mulai menurun yaitu $51 \mathrm{kV} / \mathrm{m}$ sedangkan pada saat kondisi normal sebesar 53 $\mathrm{kV} / \mathrm{m}$. Nilai medan listrik naik kembali saat tidak adanya kontaminan, nilai medannya sebesar $38 \mathrm{kV} / \mathrm{m}$.

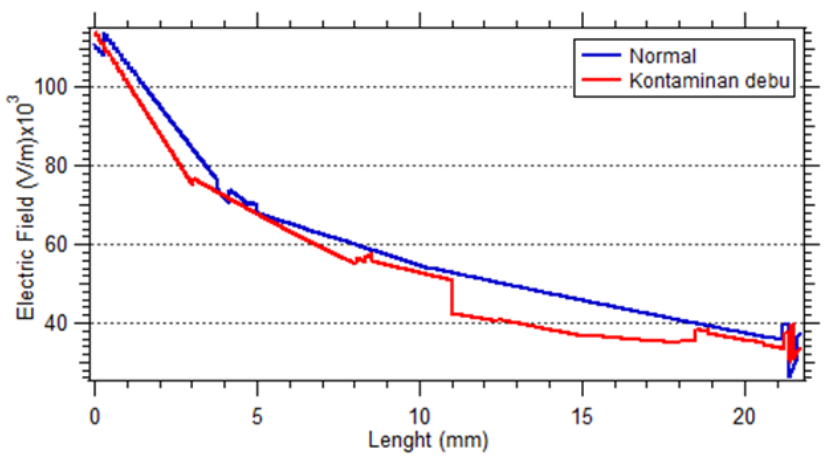

Gambar 17. Kurva perbandingan nilai medan listrik saat kondisi normal dan saat terkontaminasi debu

\section{KESIMPULAN}

Pada perbandingan nilai medan listrik antara badan dan antar sirip arrester saat keadaan diberi tegangan nominal dengan saat diberikan arus impuls mengalami perbedaan nilai yang sangat jauh, itu dikarenakan saat terkena arus impuls tegangannya sangat kecil atau hampir mendekati nol bila dibandingkan dengan tegangan nominal yang diberikan.

Pembetukan sudut kontak butir air garam mempengaruhi nilai medan listrik pada sirip pertama arrester. Pada saat mengenai butiran air garam terjadi perubahan nilai medan yang cukup signifikan. Penyebab terjadinya kenaikan nilai medan listrik yang terjadi pada sisi pembentukan sudut kontak kontaminan air garam disebabkan oleh terbentuknya sudut antara butir air garam, bahan arrester dan udara. Terbentuknya sudut tadi diimbangi dengan perbedaan nilai epsilon yang cukup besar antara air garam, bahan arrester dan udara.

Pengaruh void pada permukaan sirip pertama arrester mempengaruhi nilai medan keseluruhan pada sirip pertama arrester. Perbedaan tidak terlalu berbeda jika dibandingkan dengan keadaan normal, nilai medan listrik dengan kondisi normal berada tepat di atas nilai medan dengan kondisi adanya void.

Perbandingan nilai medan listrik dengan kontaminan debu dengan saat normal pada sirip pertama arrester. Semakin tebal debu yang menumpuk pada saerah sirip pertama arrester maka semakin jauh pula nilai medan akan menurun. Nilai medan listrik akan naik kembali saat tidak adanya kontaminan debu. Kontaminan debu mempengaruhi sifat dielektrik arrester terutama pada bagian sirip pertama arrester yang terdapat debu.

\section{DAFTAR PUSTAKA}

[1] Amir Hooshang Vaez., Mehrdad Movahedpoor., Seyed Majid Keshavarz, "Evaluating The Eefct Of Grading Rings On Distribution Of Electrical Field Enhancement Of High Voltage Surge Arrester Of 230kV', Vol. 2, pp. 140-144, 2014.

[2] T Saengsuwan and W Thipprasert. "Lightning Arrester Modeling Using ATP-EMTP", IEEE 2004

[3] Christodoulou C A., Spanias C A., Kontargyri V T., Gonos I F., Stathopulos I A, "Study of the Electric Filed Around a Metal Oxide Surge Arrester: Measurement and Simulation", High Voltage Engineering, Vol.39, No.8, August 31, 2013.

[4] B. Vahidi., R. Shariati Nasab ., J.Sh Moghani., S.A Kasha., S. Hosseinian, "Three Dimensional Analyses of Electric Field and Voltage Distribution on ZnO Surge Arrester with Broken Sheds", 2005 IEEE/PES Transmission and Distribution Conference \& Exhibition : Asia and Pacific Dalian, China.

[5] Hayt William H. And John A. Buck, "Elektromagnetika Edisi Ketujuh", Penerbit Erlangga, Januari 2006. 